\title{
Powstanie i działalność Zakładu Edukacji Międzykulturowej na Wydziale Pedagogiki i Psychologii Uniwersytetu Marii Curie-Skłodowskiej w Lublinie
}

Zakład Edukacji Międzykulturowej, utworzony w obrębie Instytutu Pedagogiki na Wydziale Pedagogiki i Psychologii Uniwersytetu Marii Curie-Skłodowskiej w Lubinie, powstał z inicjatywy ówczesnego Dziekana - prof. zw. dr. hab. Ryszarda Bery oraz kierującego wówczas Zakładem Teorii Wychowania - prof. nadzw. dr. hab. Mariusza Korczyńskiego. Po zatwierdzeniu przez rektora oraz Senat UMCS Zakład rozpoczął swoje funkcjonowanie we wrześniu 2014 roku. Jego pracownikami zostały: dr Agata Świdzińska, dr Marzena Okrasa, dr Ilona Nowakowska-Buryła oraz dr Elżbieta Kwiatkowska (zatrudniona w latach 2014-2016). Kierownictwo Zakładu 1 października 2014 roku objął prof. nadzw. dr hab. Mariusz Korczyński. Przez jeden semestr, w roku akademickim 2015/16, w Zakładzie pracował także dr Marcin Cabak.

Za powołaniem Zakładu Edukacji Międzykulturowej (ZEM) przemawiały przesłanki o charakterze globalnym, ale i lokalnym. W epoce globalizacji i integracji europejskiej coraz większego znaczenia nabiera zarówno wiedza, jak i kompetencje do działania w warunkach zróżnicowania kulturowego, zwłaszcza w sytuacji kontaktu z tym, co w znacznym stopniu odbiega od naszej codzienności. Wyodrębnienie Zakładu w strukturze Wydziału Pedagogiki i Psychologii było więc odpowiedzią na stojące przed nauczycielami, pracownikami socjalnymi i animatorami kultury aktualne wyzwanie, jakim jest kształtowanie u siebie oraz w swym otoczeniu postawy akceptacji Innego, tolerancji wobec odmienności, a także umiejętności spojrzenia na rzeczywistość w różnych kontekstach kulturowych czy religijnych. Z drugiej strony - historyczna wielokulturowość Lublina i województwa lubelskiego, obecność obcokrajowców wynikająca z napływu imigrantów i studentów cudzoziemskich czy też dynamiczne wielopłaszczyznowe kontakty naszego miasta z Ukrainą skłoniły do tego, by na lubelskiej uczelni zaistniał Zakład podejmujący dyskurs naukowy oraz działalność edukacyjną w obszarze pedagogiki międzykulturowej. 
Jeszcze przed powołaniem Zakładu jego późniejsi pracownicy, zarówno od strony naukowej, jak i dydaktyczno-organizacyjnej, zaangażowani byli w różne prace tematycznie powiązane z szeroko pojętą problematyką międzykulturową. Wśród najważniejszych działań w tym zakresie, w czasie bezpośrednio poprzedzającym utworzenie ZEM, z pewnością warto wymienić publikację monografii autorstwa R. Bery i M. Korczyńskiego pt.: Dystans społeczny emigrantów polskich wobec „obcych” $i$, innych” - wydanej w języku polskim i angielskim, współredagowanie przez M. Korczyńskiego książki Komunikacja społeczna $w$ i dla multikulturowości: perspektywa edukacyj$n a^{2}$, liczne artykuły A. Świdzińskiej - dotyczące m.in. adaptacji i integracji imigrantów, funkcjonowania dzieci cudzoziemskich w szkole oraz edukacji i animacji międzykulturowej, a także publikacje I. Nowakowskiej-Buryły na temat rozwijania kompetencji interkulturowej uczniów, przekazu kulturowego w mediach edukacyjnych czy stereotypów w postrzeganiu innych nacji przez dzieci.

We wspomnianym okresie pracownicy, w ramach obowiązków dydaktycznych, prowadzili na studiach I i II stopnia zajęcia z pedagogiki międzykulturowej oraz edukacji regionalnej i międzykulturowej. Dzięki pozyskaniu finansowego wsparcia UE uruchomiono także studia „Nauczyciel europejski - studia podyplomowe w zakresie edukacji europejskiej, regionalnej i międzykulturowej". Jak podkreślała dr A. Świdzińska, będąca koordynatorem tych studiów, zamysł połączenia w jedną ścieżkę kształcenia trzech obszarów edukacji: europejskiej, regionalnej i międzykulturowej - opierał się na przekonaniu o ich nierozłączności i współzależności. Zespolenie edukacji europejskiej - wspomagającej procesy integracji europejskiej z edukacją regionalną - eksponującą kulturowe zróżnicowanie regionów oraz edukacji międzykulturowej - nastawionej na rozumienie i wyjaśnianie interakcji między kulturami, służyć miało wzajemnemu uzupełnianiu, wzbogacaniu i podtrzymywaniu różnorodności kulturowej ${ }^{3}$.

1 R. Bera, M. Korczyński: Dystans społeczny emigrantów polskich wobec „obcych” $i$ „innych". Lublin 2012, UMCS. Tytuł anglojęzycznej wersji publikacji: Social distance of Polish emigrants towards "strangers" and "others".

2 W. J. Maliszewski, M. Korczyński, K. Czerwiński (red.): Komunikacja społeczna w i dla multikulturowości: perspektywa edukacyjna. Toruń 2012, Wydawnictwo Adam Marszałek.

3 Szersze informacje o koncepcji studiów „Nauczyciel europejski...” można znaleźć m.in. w artykule A. Świdzińskiej: Wybrane konteksty edukacji międzykulturowej na Lubelszczyźnie. „Edukacja Międzykulturowa” 2013, nr 2. 
Opisane działania, choć czasowo uprzedzały moment ukonstytuowania się Zakładu, z pewnością były ważnym przyczynkiem do jego stworzenia, wskazywały bowiem na wielorakie doświadczenia przyszłych pracowników w tym obszarze i dawały stabilne podstawy do dalszej wspólnej pracy.

Aktualnie Zakład Edukacji Międzykulturowej koncentruje swoją działalność naukowo-badawczą wokół kwestii wielo- i międzykulturowości, kontaktów między reprezentantami różnych kultur i religii, kompetencji międzykulturowych oraz społeczno-kulturowej tożsamości w dynamicznie zmieniającym się świecie, uwarunkowanych globalną migracją, w tym aktywnie rozwijającą się polską emigracją zarobkową, bliskością pogranicza polsko-ukraińskiego oraz funkcjonowaniem mniejszości narodowych, etnicznych i religijnych. Pracownicy Zakładu obejmują refleksją teoretyczną oraz badaniami empirycznymi następujące problemy:

- postawy i systemy wartości grup zróżnicowanych kulturowo (prof. nadzw. dr hab. M. Korczyński),

- tożsamość kulturowa mieszkańców pogranicza polsko-ukraińskiego (prof. nadzw. dr hab. M. Korczyński),

- kompetencje międzykulturowe pracobiorców wielokulturowego rynku pracy (prof. nadzw. dr hab. M. Korczyński),

- kompetencje międzykulturowe nauczycieli i uczniów - uwarunkowania i sposoby kształcenia (dr A. Świdzińska, dr I. Nowakowska-Buryła),

- kompetencje inter religijne absolwentów studiów pedagogicznych (dr Ilona Nowakowska-Buryła),

- zagadnienia wzajemnego współżycia i komunikowania się w warunkach wielokulturowości (dr Marzena Okrasa, dr Ilona Nowakowska-Buryła),

- specyfika i uwarunkowania edukacji międzykulturowej oraz pracy z dziećmi cudzoziemskimi w polskiej szkole (dr Ilona Nowakowska-Buryła, dr A. Świdzińska),

- problemy akulturacji cudzoziemców w Polsce (dr A. Świdzińska),

- oświata, opieka i wychowanie w społeczeństwach wielokulturowych w aspekcie historycznym i współcześnie (dr Marzena Okrasa),

- wizja człowieka i świata z perspektywy różnych kultur i religii, np. judaizm, prawosławie, islam, hinduizm (dr Ilona Nowakowska-Buryła),

- edukacja do wartości w wymiarze globalnym (dr A. Świdzińska).

Od momentu powstania Zakładu jego pracownicy systematycznie, czynnie uczestniczą $w$ konferencjach organizowanych przez wiodące ośrodki badań międzykulturowych: cieszyński i białostocki. Ostatnio były to: XIII Międzynarodowa Konferencja „Polityka edukacyjna w kształtujących się spo- 
łeczeństwach wielokulturowych" w Lipowym Moście w dniach 29-31 maja 2016 roku oraz Międzynarodowa Konferencja „Spotkania transgraniczne - mniejszości narodowe i etniczne", która odbyła się w Ustroniu w czerwcu 2016 roku. Wszyscy pracownicy ZEM wygłosili także referaty podczas IX Ogólnopolskiego Zjazdu Pedagogicznego: „Ku życiu wartościowemu. Idee - koncepcje - praktyki” w Białymstoku we wrześniu 2016 roku.

Jako Zakład jesteśmy także współorganizatorami konferencji dotyczących problematyki międzykulturowej. W czerwcu 2015 roku, wspólnie z Zakładem Białorutenistyki Instytutu Filologii Słowiańskiej oraz Zakładem Historii Krajów Europy Wschodniej Instytutu Historii UMCS, zorganizowaliśmy Międzynarodową Konferencję Naukową „Polsko-białoruskie związki kulturowe, literackie i językowe”, która odbyła się w Wisznicach - niedaleko granicy z Białorusią. Zakład koordynował także działania sekcji międzykulturowej podczas Międzynarodowej Konferencji Naukowej pt. „Psychopedagogiczne problemy edukacji i funkcjonowania człowieka - teoria i praktyka" organizowanej przez Wydział Pedagogiki i Psychologii UMCS w dniach 26-27.11.2015. W roku 2016 współorganizowaliśmy odbywającą się w dniach 12-14 września w Zakopanem międzynarodową konferencję „Komunikowanie społeczne w edukacji”. Było to już XVII spotkanie, na którym omawiane były $\mathrm{m}$.in. takie zagadnienia, jak: kompetencja w porozumiewaniu się w środowisku wielokulturowym a kompetencje komunikacyjne; szkoła i instytucje pracy socjalnej w środowisku wielokulturowym; kompetencje komunikacyjne nauczycieli i pracowników socjalnych w warunkach międzykulturowości czy też kompetencje komunikacyjne w edukacji imigrantów. Wspomniana konferencja ma charakter cykliczny, a jej współorganizatorem byliśmy już dwukrotnie.

Przejawem aktywności naukowej Zakładu są również powstające dysertacje doktorskie. Pod kierunkiem naukowym prof. nadzw. dr. hab. Mariusza Korczyńskiego finalizowane są aktualnie dwie prace. Pierwsza z nich - autorstwa mgr Katarzyny Dąbrowskiej - nosi tytuł Modyfikacja postaw uczniów szkoły podstawowej wobec osób odmiennych kulturowo. Przedmiotem badań doktorantki są postawy uczniów szkoły podstawowej wobec osób odmiennych kulturowo, a celem pracy - próba określenia efektywności oddziaływania edukacyjnego z zakresu edukacji międzykulturowej na uczniów szkoły podstawowej oraz ustalenie jego wpływu na postawy wobec osób odmiennych kulturowo. Podstawową metodę badawczą przygotowywanej pracy stanowi eksperyment pedagogiczny. Druga doktorantka - Ekaterina Skakowska, prowadzi badania terenowe na terytorium Syberii, obejmując 
nimi społeczności mieszkających tam Polaków. Tematem jej pracy doktorskiej jest Poczucie tożsamości kulturowej osób pochodzenia polskiego w regionie wschodniosyberyjskim.

Działalność dydaktyczna Zakładu Edukacji Międzykulturowej związana jest z kształceniem przyszłych pedagogów i nauczycieli w zakresie edukacji międzykulturowej dla potrzeb ich przyszłej pracy zawodowej oraz z kształceniem studentów różnych specjalności ukierunkowanym na nabycie przez nich kompetencji do funkcjonowania i aktywności w społecznościach zróżnicowanych kulturowo. Pracownicy prowadzą wykłady i ćwiczenia na studiach licencjackich oraz na uzupełniających magisterskich - aktualnie są to takie przedmioty, jak: pedagogika międzykulturowa, wprowadzenie do edukacji międzykulturowej, edukacja wielo- i międzykulturowa, wprowadzenie do zagadnień zróżnicowania kulturowego, antropologia kulturowa, migracje na europejskim rynku pracy, międzykulturowe aspekty doradztwa zawodowego i personalnego, metody i formy pracy w środowiskach zróżnicowanych kulturowo, edukacja integracyjna i kulturowa, edukacja antydyskryminacyjna, kultura w Unii Europejskiej oraz wiedza o kulturze.

Treści i zakres prowadzonych zajęć systematycznie są poszerzane i aktualizowane - adekwatnie do potrzeb edukacyjnych oraz warunków społecznych w skali międzynarodowej, ogólnopolskiej lub lokalnej. Obecnie trwają prace nad uruchomieniem specjalności: pedagogika wczesnoszkolna z edukacją międzykulturową na studiach magisterskich II stopnia, które poszerzałyby wiedzę słuchaczy na tematy powiązane z wielokulturowością oraz kształtowały kompetencje do nauczania, wychowywania i działania w duchu tolerancji, szacunku dla odmienności lub w warunkach zróżnicowania kulturowego.

Dodatkowe działania, jakie podejmują pracownicy Zakładu, to między innymi:

- koordynacja działań edukacyjnych w województwie lubelskim w zakresie edukacji globalnej wśród nauczycieli w ramach współpracy z Ośrodkiem Rozwoju Edukacji w Warszawie - od roku 2011,

- prowadzenie szkoleń i warsztatów dla nauczycieli z Polski z zakresu kształtowania kompetencji międzykulturowych,

- współpraca z pracownikami Wojewódzkiego Urzędu Pracy w celu przedstawienia wyników badań nad lubelskim rynkiem pracy wśród studentów kierunku: praca socjalna ${ }^{4}$,

4. Kobieta przedsiębiorcza - perspektywa Lubelszczyzny. W: Badania i analizy rynku pracy w województwie lubelskim 2015, nr 1(3), WUP, s. 3-7. 
- współpraca z Lubelskim Centrum Wolontariatu - szczególnie w programie Omnes Gentes, w ramach którego lubelscy studenci obcokrajowcy prezentują dziedzictwo kulturowe swoich krajów.

Ponadto dr A. Świdzińska pełni funkcję eksperta w ramach prac nad Polską Kartą Kompetencji Międzykulturowych (ORE), natomiast prof. nadzw. dr hab. M. Korczyński wchodzi w skład członków zespołu redakcyjnego czasopisma „Studia Białorutenistyczne” oraz jest stałym recenzentem czasopisma „Edukacja Międzykulturowa”. 